DOI: 10.34015/2523-4552.2019.3.23

УДК 343.8

Махніцька К. Г., аспірант кафедри кримінального права та правосуддя Міжнародного економіко-гуманітарного університету імені академіка Степана Дем'янчука

\title{
ПРО РОЛЬ ЗАБОРОНЕНИХ У МІСЦЯХ ПОЗБАВЛЕННЯ ВОЛІ ПРЕДМЕТІВ У МЕХАНІЗМІ ВЧИНЕННЯ ЗЛОЧИНІВ ЗАСУ ДЖЕНИМИ
}

У статті йде мова про таку умову, що сприяє вчиненню злочинів засудженими до позбавлення волі, як наявність у цих осіб заборонених предметів, речовин і засобів, а також про деякі шляхи ії усунення, блокування, нейтралізації тощо.

Ключові слова: місия позбавлення волі; засуджений; причина; умова; злочин; заборонені предмети, речовини та засоби; механізм вчинення злочину.

В статье речь идет о таком условии, которое способствует совершению преступлений осужденными к лишению свободы, как наличие у этих лиц запрещенных предметов, веществ и средств, а также о некоторых путях их ликвидации, блокирования, нейтрализации.

Ключевые слова: места лишения свободы; осужденный; причина; условия; преступление; запрещенные предметы, вещества и средства; механизм совершения преступления.

Постановка проблеми. Як свідчить практика, щорічно з боку засуджених, які відбувають покарання у виді позбавлення волі, вчиняються від 200 [1, с. 1] і більше злочинів [2, с. 213-214]. При цьому, однією з умов, що сприяли їх вчиненню була наявність у цих осіб предметів, виробів і речовин, зберігання і використання яких засудженими заборонено відповідно до додатка 3 до Правил внутрішнього розпорядку установ виконання покарань (далі - ПВР УВП) [3] та у загальних рисах ст. 102 Кримінально-виконавчого кодексу (КВК) України [4].
Більш того, через низький рівень та ефективність реалізації в установах виконання покарань заходів запобіжного характеру, що пов'язані із проведенням обшуків території охоронюваних об'єктів, а також засуджених, їх речей і предметів, щорічно кількість вилучених у цих осіб заборонених засобів є сталою та однаковою у розрахунку на 1 тис. засуджених.

Показовими у цьому контексті $\epsilon$ статистичні дані, які характеризують зазначене явище що стосуються 1992-2016 рр. Так, у 1992 році (першому звітному періоді часів не- 
залежності України) у засуджених, які відбували покарання у виді позбавлення волі на певний строк, було вилучено майже 500 літрів спиртних напоїв та більш ніж 20 тон браги [5, c. 2]. I це при тому, що в Основних напрямах реформи кримінальновиконавчої системи в УРСР, які були затверджені постановою Кабінету Міністрів УРСР, було закріплено таке завдання, як розширення асортименту дозво-лених для засуджених у місцях позбавлення волі предметів індивідуального та колективного користування [6, с. 7].

Суттєво не змінилась зазначена ситуація і в 1999 році (першому звітному році Державного департаменту України з питань виконання покарань (ДДУПВП) після його виведення 3 підпорядкування 3 MBC України у 1998 році). Зокрема, у 1999 році у засуджених, позбавлених волі, було вилучено 738,4 літра спиртних напоїв та інших заборонених предметів і речовин (8 тис. 244 грами наркотичних речовин, 60 тис. грн., 9 тис. 235 доларів США) [7, с. 19].

Аналогічні показники 3 цього приводу мали місце й у 2011 році (першому звітному періоду після підпорядкування органів та установ виконання покарань Міністерству юстиції України), а саме: у засуджених, які тримались у місцях позбавлення волі, вилучено 33,7 літра спиртних напоїв, 6 тис. 875 літрів браги, 934 грами наркотичних речовин та інших заборонених предметів [8, c. 7].

У свою чергу, у 2015 році у засуджених, позбавлених волі, було вилучено 70 літрів спиртних напоїв та 7 тис. 535 літрів браги, а також інших заборонених предметів [9, с. 7]. Ці ж тенденції збереглись й у подальші роки [1, с. 17].

Постановка завдання. Таким чином, слід визнати, що в наявності складна практична проблема, яка потребує вирішення у тому числі й на теоретичному рівні. Виходячи 3 цього, головним завданням наукової статті стала розробка об грунтованих шляхів запобіжного характеру, спрямованих на усунення, нейтралізацію, ліквідацію умов, які сприяють надходьженню до засуджених, позбавлених волі, тих предметів, речовин і засобів, які використовуються ними у ході вчинення злочинів.

Аналіз останніх досліджень і публікацій. Результати вивчення наукової літератури показали, що, питаннями, які стосуються запобігання потрапляння до осіб, які відбувають покарання у виді позбавлення волі активно займаються як кримінологи, так i учені кримінальновиконавчого профілю. До таких можна віднести таких із них, як O. М. Бандурка, I. Г. Богатирьов, В. В. Василевич, В. В. Голіна, Б. М. Головін, Т.А.Денисова, О. М. Джужа, О. Г. Колб, І. М. Копотун, В. М. Конопельський, О. В. Лисодєд, В. А. Меркулова, А. В. Савченко, А. Х. Степанюк, М. С. Пузирьов, І. С. Яковець та ін.

Поряд 3 цим, враховуючи зазначені вище тенденції розвитку даного суспільно небезпечного явища, що склались нині у місцях позбавлення волі, а також роль заборонених предметів у механізмі виникнення злочинів з боку засуджених, які тримаються в УВП, слід визнати, що актуальність, теоретичне та практичне значення означеної тематики дослідження є очевидною, що й 
стало вирішальним при виборі теми цієї наукової статті.

Виклад основного матеріалу. В кримінології під умовами розуміють різноманітні явища, процеси, обставини, які сприяють або створюють можливість виникнення та прояву причини, яка породжує наслідок [10, с. 188]. При цьому, як довів А. П. Закалюк, обумовлення відносяться до одного з видів детермінації, який полягає у створенні можливості (ймовірності) настання наслідку через один з двох або обома функціональними способами: сприянням формуванню причини і сприянням (створенням умов) для її реалізації [10, с. 191].

Виходячи з цього, слід у кожній ланці причинного ланцюга, крім самої причини, враховувати наявні й інші, пов'язані з нею детермінанти, а саме: умови формування причини цієї ланки та умови, які сприяють настанню наслідку дії зазначеної причини, позаяк у цій ланці можуть бути присутні й інші різновиди детермінантів, зокрема корелянти (на переконання А. П. Закалюка, всі детермінанти цієї ланки становлять їі детермінуючий комплекс [10, с. 191].

Саме зазначений методологічний підхід і був застосований у цій роботі при з'ясуванні змісту їі предмета. Така позиція дозволяла встановити декілька обставин, що сприяють проникненню до засуджених, які відбувають покарання у виді позбавлення волі на певний строк, заборонених для них на нормативноправовому рівні предметів, виробів і речовин, зберігання і використання яких не дозволяється, а саме:

1. Відповідно до вимог п. 14 ст. 92 Конституції України, діяльність органів та установ виконання пока- рань має визначатись виключно законами.

У той самий час, перелік заборонених предметів тощо для засуджених, позбавлених волі, зазначений у підзаконному нормативноправовому акті (ПВР УВП), що, з огляду змісту принципу верховенства права, який закріплений у ст. 8 Основного закону, не можна визнати правильним підходом законодавця.

Зазначена обставина, як показує практика виконання - відбування покарання у виді позбавлення волі, використовується злочинними авторитетами для здійснення тиску та вчинення різноманітних правопорушень, включаючи й спроби незаконного зберігання і використання заборонених предметів. При цьому, не дивлячись на те, що у ч. 7 ст. 102 КВК України зазначено, що перелік і кількість предметів і речей, які засуджені можуть мати при собі визначається нормативно-правовими актами Міністерства юстиції України, вказана «ремарка» законодавця не може розглядатись як така, що відповідає вимогам Конституції України.

Саме на це акцентує увагу п. 2 постанови Пленуму Верховного Суду України від 09 листопада 1996 року № 9 «Про застосування Конституції України при здійсненні судочинства», встановлювати чітку ієрархію нормативно-правових актів (норми Основного закону; закони; підзаконні нормативно-правові акти) [11, c. 136].

Враховуючи зазначену колізію та протиріччя норм КВК і Конституції України, засуджені вважають, що встановлені у ПВР УВП заборони щодо предметів, виробів і речовин $\epsilon$ колективним «витвором» персоналу 
Державної кримінально-виконавчої служби (ДКВС), який входить до системи Міністерства юстиції України, а тому використовують різноманітні форми і способи протидії адміністрації УВП, у тому числі й шляхом купівлі-продажу заборонених предметів у місцях позбавлення волі. I, що більш небезпечно, використовують їх при вчиненні повторних злочинів у ході відбування даного покарання.

Так, 19 квітні 1992 р. у виправній колонії №52 УМВС України у Донецькій області після вживання, виготовленого в камері самогону, засуджені 3. та Н., використовуючи заточку, вчинили умисне вбивство засуджених К. та Б., а потім нанесли умисні тілесні пошкодження засудженомy М. [5, с. 7].

06.01.1999 р. у гуртожитку для засуджених Кіровоградської виправної колонії № 6 після вживання спиртних напоїв між засудженими 0 . та М. виник конфлікт, внаслідок якого саморобним ножем було вбито засудженого М. [7, с. 11].

07.10.2011 p. засуджений Л., який відбував покарання у Бердичівському виправному центрі № 108, самовільно залишив контрагентський об'єкт, вжив спиртні напої та вчинив зґвалтування малолітньої особи $[8$, с. 5$]$.

18.04.2015 р. у приміщенні харчоблоку Городищенської виправної колонії № 96 на грунті раптово виниклої конфліктної ситуації двоє засуджених за допомогою заточених металевих пластин нанесли один одному колото-рублені рани спини та голови [9, с. 6].

2. Не дивлячись на прийняття 14 квітня 2014 року Закону України «Про приведення умов тримання засуджених до позбавлення волі до
Європейських стандартів» [12], що відображено у змісті Концепції реформування (розвитку) пенітенціарної системи України, схваленої розпорядженням Кабінету Міністрів України від 17 вересня 2017 року, досі порядок виконання-відбування даного покарання в Україні не відповідає нормам не лише європейського, але й міжнародного права у сфері кримінально-виконавчої діяльності.

Мова у даному випадку ведеться про те, що у Переліку предметів, виробів і речовин, збереження яких заборонено (додаток 3 до ПВР УВП), зазначені ті із них, які широко використовуються в УВП відповідно до інших норм КВК. Так, у главі 19 (ст. 123-128) даного Кодексу визначені заходи виховного впливу на засуджених до позбавлення волі, що в тому числі передбачають використання певних предметів, які входять у перелік заборонених.

Зокрема, у додатку 3 до ПВР УВП зазначено про такі із них, як: телевізори, мобільні телефони, комп'ютерну техніку, тощо, користування якими дозволяється у розрахунку - один на відділення соціально-психологічної служби, або на жилу секцію (камеру), що $є$ анахронізмом минулих років та, зокрема, тією забороною, яка була встановлена для засуджених ще у так звану «радянську епоху» та не відповідає у тому числі змісту Закону України «Про приведення умов тримання засуджених до позбавлення волі до Європейських стандартів».

Виходячи з цього, слід визнати, що видозміна ч. 7 ст. 103 КВК та додатку 3 до ПВР УВП є очевидною.

3. Як свідчить практика та результати спеціальних наукових досліджень [14], засуджені, які відбува- 
ють покарання у виді позбавлення волі, об'єктивно піддаються впливу та функціонують у площині офіційних приписів, що визначені у кримінально-виконавчому законодавстві, та кримінальної субкультури, вимоги якої $є$ не менш жорсткими, а, подекуди, й більш жорстокими ніж, наприклад, заходи стягнення, які застосовуються до цих осіб згідно вимог ст. 132 КВК. При цьому однією з необхідних складових змісту кримінальної субкультури $\epsilon$ активна участь засуджених у їі дотриманні та розповсюдженні, а також у незаконному зберіганні та використанні предметів, виробів і речовин, які заборонені у місцях позбавлення волі.

У такій ситуації протидіяти зазначеному явищу тільки кримінально-виконавчими засобами реагування (у виді заборони; застосування заходів дисциплінарної та інших видів юридичної відповідальності; вилучення цих предметів у каналах їх надходження до засуджених тощо) є недостатнім видом діяльності, позаяк дана проблема потребує системного підходу, який передбачає не тільки раціональне та ефективне використання при цьому можливостей загальносоціального характеру. До них, зокрема, відносяться заходи щодо підвищення загальної культури населення, яка спрямована на витіснення із свого обігу кримінальної субкультури; нетерпимість суспільства до її проявів на всіх рівнях життєдіяльності (побутовому, корпоративному, державному).
4. Інші обставини. До таких, у першу чергу, відносяться ті, що пов'язані з організацією харчування засуджених, позбавлених волі, та стосуються тих заборон, які визначені в додатку 5 ПВР УВП та встановлені в переліку продуктів харчування, виробів і речовин, які засуджені можуть отримувати в посилках (передачах), купувати в крамницях УВП та зберігати при собі.

Як і в попередніх випадках, їх виділення у сьогоденні, особливо у контексті положень Концепції реформування (розвитку) пенітенціарної системи України 2017 року $\epsilon$ об'єктивно обумовленим та невідкладним кроком, покликаним на підвищення рівня ефективності запобіжної діяльності з питань усунення причин і умов потенційної злочинності, а також блокування, нейтралізації, усунення тощо детермінант, які сприяють проникненню до засуджених у місцях позбавлення волі заборонених предметів, речовин і засобів.

Висновки. Таким чином, слід констатувати, що в наявності складна прикладна проблема, яка не тільки стосується змісту кримінальновиконавчої діяльності, але й тісно пов'язана із загальносоціальними цінностями та потребами, вирішення яких неможливе без комплексного підходу та без ефективного використання при цьому потенціалу всіх суб'єктів запобігання злочинам, (державних, включаючи правоохоронні органи; громадських інституцій та окремих громадян, зокрема i засуджених). 


\section{Список використаних джерел}

1. Про стан правопорядку, ізоляції та нагляду, діяльність підрозділів охорони, пожежної безпеки та воєнізованих формувань Державної кримінально-виконавчої служби України у 2016 році : Інформаційний бюлетень. Київ : Департамент ДКВС Міністерства юстиції України, 2017. 34 с.

2. Колб О. Г. Установа виконання покарань як суб’єкт запобігання злочинам : дис... док. юрид. наук : 12.00.08 / Національна академія внутрішніх справ України. Київ : 2007. 513 с.

3. Правила внутрішнього розпорядку установ виконання покарань : затв. наказом Міністерства юстиції України від 28 серпня 2018 року № 2823/5 : Офіц. текст. Київ : Алерта, 2019. 220 с.

4. Кримінально-виконавчий кодекс України : прийнятий 11 липня 2003 року. Відомості Верховної Ради України. 2004. № 3-4. Ст. 21.

5. Оперативно-служебная деятельность учреждений уголовноисправительной системы МВД Украины: Информ. бюллетень. Киев : ГУИН МВД Украины, 1993. № 4.46 с.

6. Основные направления реформы уголовно-исполнительной системы в Украинской ССР: утвержд. постановлением Кабинета Министров Украинской ССР от 11.07.1991 г. № 88. Киев : ГУИН МВД УССР, 1991. 18 с.

7. Оперативно-службова та виробничо-господарська діяльність органів і установ виконання покарань України у 1999 році: Інформ. бюлетень. Київ : ДДУПВП, 2000. № 4.84 c.

8. Про діяльність підрозділів охорони, нагляду і безпеки кримінальновиконавчих установ у 2011 році : Інформ. бюлетень. Київ : ДПтС України, 2011. 69 с.

9. Про діяльність підрозділів охорони, нагляду і безпеки кримінальновиконавчих установ у 2015 році. Київ : ДПтС України, 2016. 44 с.

10. Закалюк А. П. Курс сучасної української кримінології: теорія і практика : У 3 кн. Київ : Видавничий Дім «Ін Юре», 2017. Кн. 1: Теоретичні засади та історія кримінологічної науки. 424 с.

11. Про застосування Конституції України при здійсненні судочинства : постанова Пленуму Верховного Суду України від 09.11.1996 № 9. Постанова Пленуму Верховного Суду України у кримінальних справах / упоряд. В.В. Рожнова, А. С. Сизоненко, Л. Д. Удалова. Київ : ПАЛИВОДА А. В., 2011. С. 136-141.

12. Про приведення умов тримання засуджених до позбавлення волі до європейських стандартів : Закон України від 14 квітня 2014 року. Голос України. 06.05.2014. № 87.

13. Про Концепцію реформування (розвитку) пенітенціарної системи України: розпорядження Кабінету Міністрів України від 17 вересня 2017 року. Урядовий кур'єр. 22.09.2017. № 178.

14. Крикушенко О. Г. Сучасна субкультура місць позбавлення волі та її запобігання персоналом установ виконання покарань: дис... канд. юрид. наук : 12.00 .08 / Класичний приватний університет. Запоріжжя, 2015. 253 с.

\section{References}

1. Kolb, 0. G. (2007). Ustanova vykonannia pokaran yak sub'iekt zapobihannia zlochynam (Dys... dokt. yuryd. nauk). Natsionalna akademiia vnutrishnikh sprav Ukrainy. Kyiv [in Ukrainian].

2. Zakaliuk, A. P. (2017). Kurs suchasnoi ukrainskoi kryminolohii: teoriia i praktyka : U 3 kn. Kn. 1: Teoretychni zasady ta istoriia kryminolohichnoi nauky. Kyiv: Vydavnychyi Dim «In Yure» [in Ukrainian]. 
3. Krykushenko, 0. H. (2015). Suchasna subkultura mists pozbavlennia voli ta yii zapobihannia personalom ustanov vykonannia pokaran (Dys... kand. yuryd. nauk). KPU. Zaporizhzhia [in Ukrainian].

E. Makhnitskaya, Postgraduate Student of Department of criminal right and justice of International Universityof Economics and Humanities Academician Stepan Demianchuk

\section{On the role of prohibited in places of deprivation will items in the mechanism of committing crimes convicted}

The article deals with such a condition that contributes to the commission of crimes sentenced to imprisonment, such as the presence of prohibited items, substances and means of these persons, as well as some ways to eliminate them, block, neutralize, etc.

As practice shows, 200 or more crimes are committed annually by convicted prisoners. At the same time, one of the conditions that facilitated their commissioning was the presence in these persons of objects, articles and substances, the storage and use of which were convicted by the prisoners in accordance with Annex 3 to the Rules of Internal Order of the Penitentiary Institutions (hereinafter referred to as the JCE Jail) and in general terms - Art. 102 of the Criminal Enforcement Code (CPC) of Ukraine.

Moreover, due to the low level and effectiveness of the implementation in the institutions of punishment of preventive measures related to the searches of the territory of the protected objects, as well as the convicts, their belongings and objects, the number of prohibited funds withdrawn from these persons annually and the same for 1 thousand. convicts.

Indicative in this context are the statistics that characterize this phenomenon concerning 1992-2016. Thus, in 1992 (the first reporting period of Ukraine's independence), convicts who were serving sentences of a certain term were removed. almost 500 liters of spirits and over 20 tons of braga. This is despite the fact that in the Basic Directions of the Criminal Enforcement System Reform in the Ukrainian SSR, which were approved by the Cabinet of Ministers of the USSR, such a task was enshrined as expanding the range of items of individual and collective use of prisoners in places of deprivation of liberty.

The same situation did not change significantly in 1999 (the first reporting year of the State Department of Ukraine for the Execution of Sentences (STSDP) after its withdrawal from submission to the Ministry of Internal Affairs of Ukraine in 1998). In particular, in 1999, 738.4 liters of alcohol and other prohibited articles and substances ( 8 thousand 244 grams of narcotic substances, 60 thousand UAH, 9 thousand 235 USD, etc.) were seized from prisoners imprisoned).

Similar indicators were observed in 2011 (the first reporting period after subordination of bodies and institutions of execution of sentences to the Ministry of Justice of Ukraine), namely: 33.7 liters of liquor were confiscated from prisoners, 6875 liters of braga, 934 grams of narcotic drugs and other prohibited items. 
In 2015, 70 liters of alcoholic beverages and 7,000 535 liters of braga, as well as other prohibited items, were confiscated from prisoners imprisoned in 2015 (the first reporting period after the reform of the penal system in Ukraine). The same trends persisted in the years to come.

Keywords: places of detention; convicted; cause; conditions; the crime; prohibited items, substances and means; crime mechanism. 